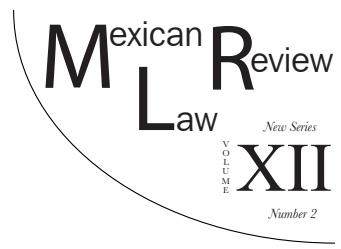

\title{
MEXICO AND THE UNITED STATES IN A COMPARATIVE SITUATIONAL APPROACH
}

\author{
Elisa Gruz RuedA*
}

\begin{abstract}
This article performs a comparative analysis of the constitutional bases of the Mexican and U.S. legal systems, and how they are expressed in two case studies. Both case studies deal with human rights as expressed through a community's relationship to territory. However, the communities in question are differentiated by their status as legal subjects. The U.S. case examines a community primarily comprised of European-American descendants; the Mexican case considers an indigenous community. Nevertheless, in both cases State involvement occurs that favors the interests of energy companies, rather than the expressed interests of the communities. The Mexican case documents an attempt to apply energy reform measures, without taking into account the rights of indigenous communities. The U.S. case showes how legal constructs have evolved to structurally favor corporate interests at the expense of human rights. These examples are used to demonstrate how democratic ideals, ostensibly protected by Mexican and U.S. constitutional systems, remain unfulfilled. While the case studies discuss how the law and the State relate to the governed, particularities exist due to the practices and procedures of the distinct governing bodies involved, and because the governed peoples - a community of European-American descent and an indigenous community in Mexico - are different legal subjects before the law. These are areas for future comparative analysis and beyond the scope of this article.
\end{abstract}

\section{Keywords: State, Property, Lau, Human Rights.}

RESUMEN: Este artículo realiza un análisis comparativo de las bases constitucionales de México y los Estados Unidos y su aplicación en dos casos. Se reconoce que existen puntos de comparación y otros no. Por ejemplo, en los casos que se aborda, aunque se refiere a las afectaciones territoriales relacionadas con

1 Bachelor of Laws from the National Autonomous University of Mexico. Master's and Doctorate Degrees in Anthropological Sciences from the Metropolitan Autonomous University at Iztapalapa. Research Professor at the School for Indigenous Governance and Self-Development at the Autonomous University of Chiapas (UNACH), Campus III San Cristóbal de las Casas, Chiapas. Email: elisacruzrueda@hotmail.com 
Esta revista forma parte del acervo de la Biblioteca Jurídica Virtual del Instituto de Investigaciones Jurídicas de la UNAM

los derechos humanos, son diferentes. En el caso norteamericano, tenemos una comunidad de ascendencia europea-americana, en el caso mexicano, tenemos una comunidad indígena. En ambos, se vea la participación del Estado de una manera que implícita o explícitamente favorece los intereses de las empresas de energía, más que los intereses de las comunidades en cuestión. El objetivo es mostrar cómo el ideal democrático, teóricamente sostenido y protegido por los sistemas constitucionales tanto mexicano como norteamericano, en realidad no se cumple. El caso mexicano documenta el intento de aplicar medidas de reforma energética, sin tener en cuenta los derechos de las comunidades indígenas y sus pueblos. En el caso de América del Norte, el marco normativo ha evolucionado para favorecer estructuralmente los intereses corporativos, a expensas de los derechos humanos. Si bien los estudios de caso exponen la relación de la ley y el Estado con los gobernados, existen particularidades: las prácticas y procedimientos de los distintos órganos de gobierno involucrados, y el tratamiento de las comunidades ante la ley, por un lado, una comunidad de ascendencia europeo-estadounidense, por otro una comunidad indígena en México. Estas son áreas para futuros análisis comparativos, más allá del alcance exploratorio inicial de este artículo.

Palabras Clave: Estado, Propiedad, Derecho, Derechos Humanos.

\section{Table of Gontents}

I. INTRODUCTION

II. The Western Legal System and the Rule of Law: Mexico and the United States.

III. The Mexican Constitution: a Brief History

1. The Original Property of the Nation .......................................... 145

2. Energy Reform: The Second Agrarian Counter-Reform

3. Recognition of, and Demand for, Rights in Mexico - Between

Negotiation and the Right to Prior, Free, and Informed

Consultation: Kimbilá, Municipality Of Izamal, Yucatán.....

IV. The Constitution in the Gase of the United States:

A BRIEF History

1. A Brief Note on Property Ownership

2. U.S. Legal Structures and Challenges in Protecting the Land....... 152

A. The Environmental Regulatory System: Stumbling Blocks ..... 153

B. Corporate Personhood and Corporate Rights ........................ 154

3. Case Study: Grant Township, Pennsylvania ............................... 157

A. PGE v. Grant Township......................................................... 157

B. Intervenors in PGE v. Grant Township ................................. 160

C. Pushback to Community Opposition ...................................... 161 
D. DEP v. Grant 162

E. Additional Actions .................................................................. 162

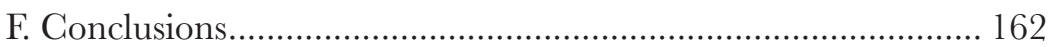

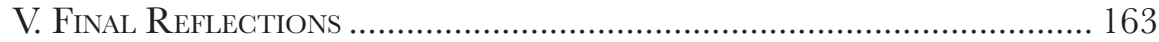

1. On The Legal Framework ……………........................................ 163

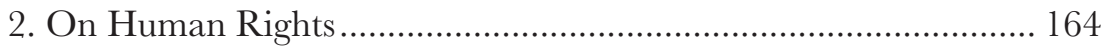

3. On Historical Processes .................................................................. 164

4. On Consultations and Public Hearings ......................................... 164

5. On the Privileged Status of Corporations ....................................... 164

6. On Democratic Governance ..................................................... 165

\section{INTRODUCTION}

This article is the product of a shared experience of two attorneys who have practiced in the Mexican legal context, specifically in the states of Chiapas, Oaxaca and Yucatán, in areas pertaining to the exercise and claiming of agrarian, indigenous, and land rights.

One of the attorneys, a lawyer from the United States (U.S.), participated in this process for two years. Upon returning to the U.S., this process served as a basis for involvement in community struggles related to the demand for rights in U.S. society. Part of this experience was having learned that being a lawyer is not confined to professional practice in court or contentious jurisdictional disputes; community lawyering involves being an agent and ally in social processes in which the affected parties take their demands for rights into their own hands, transforming legal tools into organizing tools. With a viewpoint rooted in the global South, the U.S. attorney joined community organizing efforts in Illinois and Pennsylvania that opposed fracking and advocated community municipal autonomy to confront concentrated power wielded by corporate interests, which superseded the localized interests of communities.

Given this panorama and our continuing contact as fellow attorneys in Mexico and the United States, the objective behind this article was to write about how the rights of human beings, be they citizens or not, and regardless of their ethno-cultural affiliation, are violated in both countries.

This article works from the assumption that there are points of convergence and divergence between both countries, along with coexisting tensions and agreements, and that these are due in part to the philosophical stance or worldview that form the basis for the construction of each State as a nation. Despite the difference in each system's origin - the Anglo-Saxon or common law tradition for the United States and the Romano-Germanic tradition for Mexico - a key point of convergence can be found in a shared desire for a de- 
mocracy based on fundamental ideals that are, simultaneously, antagonistic: non-interference and its counterpart, interventionism.

Without doubt, human rights violations take on different forms in the two distinct contexts. In addition to having developed two Constitutions prior to the current one, as of the year 2015 Mexico boasts over 600 constitutional reforms, whereas the United States has developed a single Constitution with various amendments. Mexico possesses a body of human rights law that is considerable in size and closely tied to the international human rights legal system. By comparison, the United States has signed and ratified relatively few international human rights legal instruments, despite being a proponent of the Universal Declaration of Human Rights of 1948 and being home to the headquarters for the United Nations. ${ }^{1}$

This article's approach examines the constitutional foundations for both countries, so as to conduct a procedural and situational analysis - as opposed to a merely normative or constitutional analysis - that focuses on understanding how the law is applied in practice.

This article is divided into three parts. The first section addresses the central concepts of the Western legal system, and particularities in each country that explain the differentiated manner in which the Mexican and U.S. states have been constructed. The second section presents cases that demonstrate how the law is invoked and applied in both countries. Final reflections are provided in the last section.

\section{The Western Legal System and the Rule of Law: Mexico and the UNITED STATES}

The Western legal system is based on the recognition of certain rights. Regardless of the basis upholding a particular legal system, each one,

employs a particular vocabulary that corresponds to distinct concepts; groups laws into distinct categories; defines the use of certain techniques with the goal of formulating the rules of the law and certain methods of interpreting them; [and] is rooted in a given conception of social order that determines both the mode of application and the very function of the law itself. ${ }^{2}$

1 Included among the few international instruments that have been signed and ratified by the United States are the International Covenant on Civil and Political Rights, ratified in 1992; the International Convention on the Elimination of All Forms of Racism, ratified in 1994; and the Convention Against Torture, ratified in 1994.

2 René David \& Camille Jauffret-Spinosi, Los Grandes Sistemas Jurídicos ContemPORÁNEOS 12 (2010), available at https://bibliotecavirtualceug.files.wordpress.com/2017/06/los-grandessistemas-juridicos-contemporaneos.pdf (last visited July 4, 2019). 
In other words, a common characteristic of both the Mexican and U.S. legal systems is that the right to be formed through a social and cultural process becomes a key reference point for understanding identity formation processes (e.g., a person's origin; who is considered to be part of a group or community), which in turn defines a people or a community in the regional and international context. At the same time, the law reveals the importance of the structural aspects that make up a country and position it in terms of its relations and power dynamics within a region and toward other nation-States.

More tangibly, a Constitution embodies the fundamental basis for the nation-State and the law. Such an instrument sets forth the sentiments of a nation, in which at least one version of the values and history of a people are captured: in other words, it is a product of the historical and cultural processes in a society. A Constitution theoretically outlines an individual's rights, duties, and responsibilities; the State's obligations and authority as the custodian of public power; and a description of how the State and the Law should function and be organized.

The construction of the Mexican and U.S. nation-States is reflected in their respective Constitutions, and in the manner by which each State relates to the different peoples inhabiting in, or interacting with, their territories. The following sections explore these relationships by engaging in a comparative dialogue.

\section{The Mexican Constitution: a Brief History}

The economic development models imposed by the Spanish Crown in the territories known as "New Spain" marked a huge setback for indigenous peoples. This model's central pillar was the concept of the indio ("Indian"), ${ }^{3}$ the purpose of which was the invisibilization of the cultural diversity of Native American communities, calling into question the nature and condition of their members as individuals, and thus effectively undermining them as the legitimate inhabitants of their homelands. This policy was centered on the accumulation of capital in the hands of a governing caste (namely, the Crown and the Church) in the colonies, in the Iberian Peninsula, and Europe in general, creating a stranglehold on indigenous communities.

Although the Laws of Burgos formally abolished the enslavement of indigenous peoples while Mexico was still a Spanish colony, these laws did not address the enslavement of other peoples, nor did they eliminate the prevailing caste structure. Following Mexico's independence from Spain, the Sentimientos de la Nación ("Sentiments of the Nation") document, drafted by José María Morelos y Pavón in 1813, abolished both the enslavement of all persons and the caste system.

3 Guillermo Bonfil Batalla, México Profundo: Una Givilización Negada 42 (1987). 
Nonetheless, despite these changes, indentured servitude was subsequently instituted as a "new model" of domination. The economic caste system, intimately linked with racial discrimination, was not abolished; rather, the new national economy continued to be closely tied to the increasingly vigorous world economy. Revolutionary ideals (e.g., an end to tributes, a raise in the daily wage, and one-time tithing, which mitigated opulence and indigence) outlined a general formulation for the development of the national economy, but did so without addressing the issues of the State either as the generator of equity or of equality rooted in diversity and, as such, as the arbiter of economic development. This model, and its subsequent iterations, have invisibilized indigenous peoples, as can be observed in the Constitutions of 1824, 1857, and 1917.

The Constitution of 1917 - which currently governs Mexico - is recognized for being founded on the claims of the Revolution of 1910, particularly for agrarian land distribution, which is at the heart of Article 27 of the Mexican Constitution. Article 27 details rights related to land, water, forests, natural resources, and strategic resources such as petroleum and uranium. To guarantee the equitable distribution of the country's wealth, the Constitution of 1917 established that the State would foster the formal conditions for balancing the interests of vulnerable sectors with those of investors and the owners of production by recognizing rights to social security, work, health, and education. This arrangement was termed the social welfare state. At the same, the central principle of recognizing the Nation as the original owner of all national territory was established.

The State's relationship with indigenous peoples - here termed "indigenous policy" - has passed through various stages: ${ }^{4}$ assimilationism, integrationism, critical indigenismo, ${ }^{5}$ participatory indigenismo, ${ }^{6}$ and the neo-indigenismo of today.

Given the aforementioned history, a key point in the construction of the Mexican State - reflected in its political Constitution, as a federal pact and the supreme law of the nation - is its relationship with indigenous peoples. This relationship is marked by an evolutionist vision that proposed, and continues to propose, the idea that indigenous communities sooner or later would and will abandon their forms of organization and their languages - which are distinct from those of Mexican society writ large. From this viewpoint,

4 Luis Villoro, Los Grandes Momentos del Indigenismo en México 11 (3RD ed. 1996).

5 Critical Indigenismo acknowledges several documents that attest to the situation of Indigenous Peoples dealing with nation-States, including: (i) the Declaration of Barbados of 1971, from the Symposium on Inter-Ethnic Conflict in South America; (ii) the Declaration of Barbados II of 1977; (iii) the Declaration of Barbados III of 1993; and (iv) the Declaration of San José on Ethno-Development of 1981. These documents also recognize the political importance and protagonism of indigenous peoples as subjects of the law whose rights should be recognized in order to achieve a plural and truly democratic nation.

6 In 1982, participatory indigenismo posited the concept of ethno-development. 
indigenous societies were and are looked down upon, as examples of primitive civilizations that represent "underdevelopment" and unfortunate circumstances that should be left behind. This idea persists, despite the existence in Mexico of a body of law devoted to individual and collective human rights that penalizes and repudiates this type of vision.

Because indigenous peoples and communities were subjected to colonial jurisdiction after the Conquest and colonial laws stripped them of their lands, the relationship between the Mexican State and indigenous peoples originates with colonialism and the Spanish Conquest. Mexican federal law, and subsequently, republican law, is rooted in this colonial history, one in which domination and plundering were legitimized by law. ${ }^{7}$

Legal instruments that have served to legitimate the expropriation of native lands by the Spanish Crown, and later the Mexican State, include the papal Bulls of Donation (also known as the Alexandrine Bulls); the legal institutions related to property, reducciones, encomiendas, and the "republic of Indians", as used by the Spanish ${ }^{8}$ to exert better control over the inhabitants of corresponding lands; and more contemporarily, the Reform and Expropriation Laws, and the Agrarian Reform. ${ }^{9}$

It should be noted that the relationship between the Mexican State and indigenous peoples varies on a regional basis. Amongst other factors, differing levels of community organization within indigenous communities produces a different dynamic vis-à-vis the State. For example, the indigenous movement in Oaxaca is distinct from that in the Yucatán Peninsula; in Oaxaca, it is more articulated and politicized, while in the Yucatán, it is not nearly as pronounced.

\section{The Original Property of the Nation}

Mexican history has been marked by a series of events that are reflected in post-1917 constitutional law and policy. Among them are a series of invasions and interventions against the Mexican State by foreign nations, which, under

7 José Ramón Medina Cervantes, Derecho Agrario (1987).

8 Jorge A. González Galván, El Estado y las Etnias Nacionales en México: la Relación entre el Derecho Estatal y el Derecho Consuetudinario 77 (1995).

9 Elisa Cruz Rueda, Derecho Indígena Dinámicas Jurídicas, Construcción del Derecho y Procesos de Disputa 50 (2014).

Regarding land distribution as a central part of the Agrarian Reform in Mexico, see: José Cruz Agüero Rodríguez \& Nelly Josefa León Fuentes, Reparto Agrario e Institucionalización de la Organización Campesina, Atlas del Patrimonio Natural, Histórico y Cultural de Veracruz: II Patrimonio Histórico 191-98 (2010). See also Manuel García Hernández, Reforma Agraria en México, 93 Observatorio de la Economía Latinoamericana 1-29 (2008), available at https://geoamericaunaffiles.wordpress.com/2011/11/reforma-agraria-en-mexico22.pdf (last visited July 4, 2019). 
the pretext of responding to alleged offenses against their citizens residing in Mexican territory or in response to alleged debts, decided to collect by appropriating Mexican resources and Mexican territories, including mainland, airspace, waters, coastlines, and seas.

This history is the underlying basis for Article 27, which both establishes that the original property of the national territory belongs to the Mexican State, and institutes safeguards to avoid subsequent pretensions of "enemy" nations appropriating the wealth and resources of the Mexican republic. Political authority is delegated to the Mexican federal government in its role as steward of the Mexican economy, encompassing the protection of the nation's resources, which for the purposes of this article shall be referred to as the "energy matrix".

Efforts to establish the Mexican State's sovereignty over matters relating to its energy matrix continued well into the $20^{\text {th }}$ century and included steps such as the nationalization of the petroleum industry in 1938 and the nationalization of the electric energy sector in 1960. Regarding the latter:

On September 1, 1960, President López Mateos announced the reform of Article 27 of the Constitution, stating that concessions to individuals for public electric energy services shall not be granted.

The nationalization process that begins on this date will conclude on December 29, 1960, with the following addition to Article 27 of the Constitution: 'It is the exclusive power of the Nation to generate, conduct, transform, distribute, and supply electric energy in order to provide electric energy as a public service. No concessions shall be granted to individuals and the nation will profit from the goods and natural resources required for such purposes.' With this measure the services that remained in the hands of foreigners were recovered. ${ }^{10}$

This history indicates that the Mexican nation had total control over its energy matrix. Over time, however, reforms carried out to the legal-judicial/ Constitutional framework dismantled these protections in such a way that transnational capital was able to return and reclaim certain components of the energy matrix.

As early as the presidential term of Miguel de la Madrid Hurtado (19821988), banking fell subject to privatization. During the presidential term of Carlos Salinas de Gortari (1988-1994), the nationalization of the petroleum industry and the electric energy sector was practically dismantled. Secondary laws that regulated the above-mentioned aspects of the Articles of the Federal Constitution were reformed, thereby permitting the privatization of both industries and marking the beginning of the neoliberal era in Mexico.

10 Doralicia Carmona Dávila, Inicia el proceso de Nacionalización de la industria eléctrica, MeMORIA POLÍTICA DE MÉXICO, http://memoriapoliticademexico.org/Efemerides/9/27091960.html (last visited July 4, 2019). 
This push toward privatization was further cemented with the agrarian counter-reform in 1992. Carlos Salinas de Gortari, upon announcing reforms to Article 27 of the Constitution of 1992 and the ensuing implementation of the new Agrarian Law, pronounced that agrarian nuclei were the owners of their lands. In actuality, however, per the original Agrarian Reform, ejidatarios and communal landholders held this right over their lands; what Salinas de Gortari was really intimating was that the counter-reforms carried out under his watch ushered in the market liberalization of land.

Further steps taken during the presidential term of Ernesto Zedillo (19942000) laid the foundation for the energy reforms that were implemented during the presidential terms of Vicente Fox (2000-2006) and Felipe Calderón (2006-2012). These measures found even greater impetus in 2013 under President Enrique Peña Nieto (2012-2018).

Taking advantage of the state of insecurity unleashed during the Calderón administration and the compromised position of left-leaning political forces, Peña Nieto's administration brought about the signing of the Pacto por México (Pact for Mexico). ${ }^{11}$ The Pact introduced structural reform by constitutionalizing a reversal of the national stewardship of Mexico's energy matrix, thereby creating a new jurisdictional structure and thus restricting the Nation's rights to its own energy matrix. The new reforms legalized forced entry into the lands and territories of indigenous and non-indigenous farmers; new rules were established to generate, store, transmit, and commercialize electric energy; mining concessions were pushed through; and oil drilling and pipeline installation were favored over landowner rights - especially those of ejidatarios and co-proprietors whose ejido or communal lands will be used for oil drilling or for the passage of oil pipelines. But not only has this new legislation contributed to the surrender of key parts of the Mexican energy sector to private hands; it has also contributed to the dismantling of any possibility of the justiciability over the lands and territories of indigenous peoples or the inclusion of such justice-based norms in national legislation.

\section{Energy Reform: The Second Agrarian Counter-Reform}

The 1992 agrarian counter-reform decreed the end of agrarian land distribution and liberalized the sale and purchase of collectively-held lands (ejido and communal). Companies, corporate entities, and financial partnerships were given permission to acquire and own lands. The agrarian legal framework that had been oriented toward social and public welfare was liberalized, adding dispositions from civil and commercial court.

11 Redacción Animal Político, Texto completo del "Pacto por México". (Dec. 3, 2012) https:// wrere.animalpolitico.com/2012/12/los-cinco-acuerdos-del-pacto-por-mexico/(last visited July 4, 2019). 
Esta revista forma parte del acervo de la Biblioteca Jurídica Virtual del Instituto de Investigaciones Jurídicas de la UNAM

Subsequently, the 2013 energy reform brought about more changes. The Secretariat of Agrarian Reform, which had been characterized by a centrist and protectionist tendency toward campesino communities, was transformed into what is now known as the Secretariat of Agrarian, Territorial, and Urban Development (SEDATU). The SEDATU is the head of the division, and in charge of the directives issued to agencies such as the Federal Agrarian Agency (Procuraduria Agraria). This transformation of name, function, and political priorities can be observed in cases in which the Secretariat and its corresponding agencies should have been present but were absent, or they were present but were clearly biased toward supporting private capital, rather than social welfare. ${ }^{12}$

\section{Recognition of, and Demand for, Rights in Mexico - Between Negotiation and the} Right to Prior, Free, and Informed Consultation: Kimbilá, Municipality of Izamal, Tucatán

Kimbila is located in the state of Yucatán in the Yucatán Peninsula. Our presence in the area came at the request of a student who is a resident of one of the towns and a member of a local indigenous organization. Our involvement has been part of a coordinated action with other colleagues who are concerned with the increasingly pronounced presence of corporate entities in the towns and villages in the area. Information regarding the situation can be accessed on a website maintained for the general public. ${ }^{13}$

Kimbila is an ejido and also the largest of five townships belonging to the Municipality of Izamal. The distance between Kimbila and the municipality's seat of governance is 12 kilometers.

According to the records of the National Agrarian Registry, Kimbilá was constituted as an ejido through an endowment of lands via the Presidential Decree of 1921. The boundaries of these lands were then extended in 1939; that same year, a total of 555 ej̈datarios were registered in Kimbilá. To date,

12 Elisa Cruz Rueda, Capítulo 9: Derecho a la Tierra y el Territorio: Demandas Indígenas, Estado y Capital en el Istmo de Tehuantepec, in Justicia Indígena y Estado: Violencias Contemporáneas (2013).

On the issue of structural reform as an area of constant tension between the Mexican State and indigenous peoples, see Articulación Yucatán, Parques eólicos amenazan la sostenibilidad en $\mathrm{Yu}^{-}$ catán: expertos (April 28, 2017), available at https://mayaenergia.wordpress.com/2017/04/28/parqueseolicos-amenazan-la-sostenibilidad-en-yucatan-expertos/(last visited July 4, 2019).

See also Diario de Yucatán, Todo Kimbilá, no solo el ejido, debe saber del parque eólico (March 21, 2016), available at http://yucatan.com.mx/yucatan/izamal/todo-kimbila-no-solo-el-ejido-debe-saber-delparque-eolico (last visited July 4, 2019).

See also Daniel Sánchez Dórame, Guarïios se oponen a construcción de presa, EXCELSIOR (August 19, 2013), available at https://www.excelsior.com.mx/nacional/2013/08/19/914331.

13 Proceso Kimbilá, Yucatán, available at https://procesokimbilayucatan.wordpress.com/ (last visited July 4, 2019). 
the census has not been updated in Kimbilá since 1939, despite the many deaths that have occurred, as well as the transfer of property from ejidatarios to other individuals who, although having possession of ejido lands, have not been recognized as ejidatarios with full rights (e.g., the right to vote in ejido assembly meetings). Further, Kimbilá has not been enrolled in the Programa de Certificación de Derechos Ejidales y Titulación de Solares (PROCEDE), a certification program for ejidal rights which, although controversial in some respects, nevertheless provides updated statistical data on communities within the program.

By invitation of a group of townspeople and ejidatarios from Kimbilá, we attended an informational meeting with the townspeople and, three days later, an ejidatario assembly meeting in which representatives of ELECNOR, a Spanish-owned company, hoped to elicit town members' agreement to the construction of a wind farm on ejido land.

During the initial meeting, information was presented regarding International Labour Organization Convention No. 169; the rights of indigenous peoples and their nations; the legal requirements for convoking an Assembly to decide the fate of ejido and communal lands; wind farms, their installation, and their "life" expectancy; and offers that companies typically make to landholders in other parts of Mexico and the world. ${ }^{14}$

The latter sparked suspicion among townspeople and ejidatarios as to the interests of ELECNOR. The meeting gave the people greater certainty regarding their right to ask for more information about the wind farm project and the earnings they could obtain before giving consent or signing any contracts. During the meeting there were many questions and concerns to which we tried to respond, highlighting ways in which companies "convince a few" who then convince others. The people asked us if they should accept the contract, and we replied, "We do not know because we have not read the contract. We do not know how much land they will occupy or the conditions needed for the installation of the wind farm, or the infrastructure they will require to distribute the energy that is generated. If you do not know, or do not have the information in front of you, then we certainly do not know, either." We also pointed out, "You cannot oppose or accept something that you do not know anything about. That is why a consultation process with sufficient information, conducted in good faith, is important".

Many young people, especially young women, expressed their indignation, stating that they believed the company was taking advantage of the needs of their fathers, mothers, and older grandparents who could no longer work the fields. As students, they aspired to be professionals, but were not willing to renounce the land that had given them so much. Many of the young people in the vocational high school expressed their interest in further research and in keeping the people informed.

14 Scott Robinson \& Ezer R. May, Riesgos y retos para el desarrollo eólico en Yucatán (Jun. 14, 2016) (unpublished dissertation) (presented at the CINVESTAV Colloquium, June 13-14, 2016, Mérida, Yucatán) (on file with the authors). 
After the informational meeting, the people asked us to attend the ej̈datario assembly meeting at which ELEGNOR representatives hoped to receive consent to install the windmills. We accepted on the condition that the people were made aware of their right to request more information and to obtain a copy of the contract in order to organize and to bring the Assembly to a halt if they felt it was necessary. We agreed to attend but not to participate.

At the ejido assembly meeting, the ejidatarios vocally objected to its proceeding via statements such as: "The formalities of prior notice have not been respected!" and "Nullify the Assembly!" and "There is no Assembly!" Nevertheless, roll was called in the presence of ELEGNOR representatives, the ejido township council, and a representative from the Federal Agrarian Agency. The meeting, however, could not be carried out because a legal quorum was not met.

After the ejido assembly, a group of ejidatarios drafted and signed a complaint to the Director of the Federal Agrarian Agency, which alleged certain facts and sought the following relief:

"FIRST.- Official intervention by the Director of the Federal Agrarian Agency given that the representative of the Agency, the Acting Agency Chief, the Legal Subdelegate of the Regional Agency Office in Yucatán, as well as the President of the Ejido Township Council, are violating our rights - as ejidatarios, as human beings, and as members of the Mayan Indigenous People.

SECOND.- Precautionary and security measures to AVOID the repetition of the irregular and illegal conduct on the part of the Acting Agency Chief and the President of the Kimbilá Township Council, insofar as their convocation of township assemblies without providing the requisite informed notice to, and without the support of a democratic mandate of, ALL EfIDATARIOS".

With this document, the foundation was laid for avoiding the possibility that State or corporate interests invested in the proceeding would improperly interpret the results of the assembly. The complaint made clear that the irregularities surrounding the convocation of, and notice for, the meeting, and the meeting's subsequent occurrence, annulled any decision that anyone might attempt to draw from it.

\section{The Constitution in the Case of the United States: \\ A Brief History}

While the formation of the United States is a complicated amalgamation of contradictory forces, certain lines of action relevant to this article can be identified, particularly those tied to economic and colonial forces. Such actions include the displacement and extermination of Native peoples, often using the law to justify such actions; the immigration of working class European settlers who fled the forces of commerce, capitalism, and land enclosure; the 
introduction and expansion of the slave trade from the African continent; the general prohibition against women as political actors; and the formation of an elite class of gentlemen who benefitted from, and sought to perpetuate, the class structure carried over from Europe. ${ }^{15}$

The U.S. Revolution emerged from this context, as did the legal structures that followed, rejecting British control of the colonies so the colonies might build their own project of westward expansion. ${ }^{16}$ The colonies formed the first U.S. constitution, known as the "Articles of Confederation," adopted in 1777 and ratified in 1781, establishing a decentralized form of government. The colonial elite, however, convened a constitutional convention in 1787 that eliminated the Articles of Confederation, and installed the current U.S. Constitution in 1789, which emulated European legal models and concentrated power in the federal government, which tended to favor economic interests. ${ }^{17}$ This resulted in the centralized federal government that continues to date, as well as a Constitution that protects economic interests, but falls short of protecting civil rights (the Bill of Rights being added to the Constitution after its drafting). ${ }^{18}$

\section{A Brief Note on Property Ownership}

Unlike Mexico's Constitution, the U.S. Constitution does not provide that all land within the country is original property of the nation. ${ }^{19}$ The Constitu-

15 See Howard Zinn, A People's History of the United States (Cynthia Merman ed., Harper \& Row 2005, 1980), Chapters 1-7. Also see ZinN at 46-48.

16 Id. at 86.

17 Charles Beard argued the Constitution was drafted to protect economic interests. Other commentators criticize this position. But, as Chemerinsky notes, "there is no doubt that the framers intended to protect economic rights." Erwin Chemerinsky, Constitutional Law: Principles and Policies, 622 (Wolters Kluwer Law \& Business, 4th ed., 2011).

18 For more reading on elite control of the Constitution's drafting, see ZinN at Chap. 5 " $\mathrm{A}$ Kind of Revolution", and Terry Bouton, Taming Democracy (Oxford University Press, 2007) at Chap. 8, "A Stronger Barrier Against Democracy". Zinn also notes: "The Constitution, then, illustrates the complexity of the American system: that it serves the interests of a wealthy elite, but also does enough for small property owners, for middle-income mechanics and farmers, to build a broad base of support. The slightly prosperous people who make up this base of support are buffers against the blacks, the Indians, the very poor whites. They enable the elite to keep control with a minimum of coercion, a maximum of law - all made palatable by the fanfare of patriotism and unity. The Constitution became even more acceptable to the public at large after the first Congress, responding to criticism, passed a series of amendments known as the Bill of Rights. These amendments seemed to make the new government a guardian of people's liberties: to speak, to publish, to worship, to petition, to assemble, to be tried fairly, to be secure at home against official intrusion. It was, therefore, perfectly designed to build popular backing for the new government. What was not made clear - it was a time when the language of freedom was new and its reality untested - was the shakiness of anyone's liberty when entrusted to a government of the rich and powerful". ZINN at 99.

19 Due to limited familiarity, the authors do not extend too far into this topic. However, this 
tion does, in Art. IV, Sec. 3, Clause 2, grant Congress the authority to manage and control all territories or other property owned by the United States. ${ }^{20}$ But, land ownership in the United States originates from various sources. In the pre-revolutionary era, colonies were private property, owned by individuals or families under private corporate charter issued by the British Crown. PostRevolution, the United States acquired land by territorial expansion, with the government often encouraging settlers to squat on and claim lands; a settler's ownership might become official following U.S. control of those territories. ${ }^{21}$

Other forms of land ownership currently exist, including state control of state lands, municipal control of municipal lands, individual private property and split estates (where surface and subsurface rights are split), and the relationship between the federal government and Indian reservations. While examples of nationalized property have and do exist, these tend to be the exception rather than the norm. All to say - the question of who owns the land within the United States does not always have a simple answer, and the default is not necessarily the federal government.

\section{U.S. Legal Structures and Challenges to Protecting the Land}

The U.S. Constitution, along with common law, are the bases for U.S. law. But, if the Constitution is a document that, amongst other concerns, prioritizes economic growth (as designed by its drafters, who were interested in expanding the fledgling country), laws that emanate from it also tend to be rooted in a particular economic logic. ${ }^{22}$ To understand how this translates in practice, it is instructive to examine land defense struggles.

Land defense struggles encounter structural impediments in the law, including challenges within the regulatory system that - albeit perhaps unintentionally - can work to the advantage of corporate interests, along with the legal doctrines of corporate personhood and corporate rights. ${ }^{23}$ What follows is a general examination of certain aspects of the U.S. legal system that com-

marks an important difference from the case of Mexico, and merits mentioning. A "history of property" in the U.S. warrants further research.

20 U.S. Const. art. IV, § 3, cl. 2.

21 ZINN at 129. White settlers often served as pawns for federal interests, "pushed into the first violent encounters, but soon dispensable," as they fought Indian tribes who defended their homelands. ZINN at 136.

22 This is not to say that movements have not attempted to counteract this framework. The Amendments enshrined crucial guarantees for civil liberties - for example, the Thirteenth Amendment abolished slavery - but not completely. Instead, slavery remained a legal option for the punishment of a crime. Michelle Alexander, The New Jim Crow, 31 (The New Press 2012) (2010).

23 Other structural challenges exist, including the doctrines of state preemption, Dillon's Rule, and particularly the Western worldview of treating land merely as property. 
munities encounter when attempting to oppose projects, usually spearheaded by corporations and usually involving land and environmental concerns.

\section{A. The Environmental Regulatory System: Stumbling Blocks}

The current U.S. environmental legal system originated in the $1970 \mathrm{~s},{ }^{24}$ and is based on a regulatory framework. Structural and philosophical characteristics, ostensibly designed to protect the land, can have the opposite effect under certain conditions.

Structurally, the regulatory system is designed to issue permits to companies. While one benefit of this system is the State's capacity to track and ideally control industrial activity, the drawback to this framework is the State's legalization of a certain degree of harm to the land. ${ }^{25}$ And, community consent to a project is not required; the environmental agency must hold public hearings to receive non-binding community input. ${ }^{26}$

Additionally, as administrations change and new agency directors are installed, political priorities can politicize agency agendas. ${ }^{27}$ This can result in political appointees from the private sector overseeing the very regulatory programs they spent a career opposing. ${ }^{28}$ Likewise, limited agency enforcement capacities due to ever-present budget constraints can compound challenges to effective environmental legal enforcement.

Philosophically, one viewpoint interprets the regulatory system as a framework that facilitates the orderly use of the land and resources by industry and other human needs. ${ }^{29}$ While this goal is not inappropriate, this can mean the

24 The creation of the environmental regulatory system was galvanized by the publication of the book Silent Spring by Rachel Carson on Sept. 27, 1962. Carson documented harms caused by pesticides and criticized the chemical industry's efforts at disinformation and officials' acceptance of industry claims. Its publication impacted national policy, prompting passage of key legislation and the creation of the EPA, and mobilized the environmental movement, leading to the first Earth Day on April 22, 1970. Mary Christina Wood, Nature's Trust 51 (John Berger ed., Cambridge University Press, 2014).

25 Id. at 65.

26 When communities reach this juncture, they might attempt to appeal the permit. Permit appeals, however, generally focus on permit application deficiencies or relied-upon science, or another technical defect. Once the company resolves those issues, it can usually resubmit its application, and receive the permit once the error is rectified. When the fundamental issue, however, is a general democratic opposition to the establishment of the project, a larger governance question comes into play, namely, who should have the ultimate authority to give final authorization to the project.

27 Id. at 85. For example, at one point U.S. President Donald Trump nominated Scott Pruitt, former Attorney General for the State of Oklahoma, to serve as the federal EPA Administrator. While Attorney General, Pruitt made a point of opposing EPA policies.

28 Id. at 85.

29 Community Environmental Legal Defense Fund (CELDF), On Community 
protection of the environment occurs as a consequence of the larger overarching goal, rather than being the main priority. ${ }^{30}$ Not all commentators, or environmental practitioners, agree with this interpretation of the system's philosophical underpinnings; still, this interpretation has gained support in certain spheres of the general public, such as in the case study discussed further below. ${ }^{31}$

The grounds used to enact environmental laws do not detract from this interpretation. The basis for federal action in the realms of civil rights, labor, and the environment did not exist independently in the Constitution (and understandably so, since those issues were not the immediate concerns of its drafters). When the U.S. Congress sought to pass laws in those areas, it had to turn to an unlikely foothold - the Commerce Clause. ${ }^{32}$ Environmental laws were passed by arguing that waterways, air, waste, and wildlife are part of interstate commerce, meaning Congress can enact laws to protect the interstate flow of these "articles of commerce". 33

Some environmental advocates thus argue that this structure, "carries the seed of its own repudiation--an implicit recognition that the existing constitutional structure is not rights-based but commerce-based, which then requires an exploration of whether a structure solely focused on protecting commerce can ever provide a foundation for rights and sustainability". ${ }^{34}$

\section{B. Corporate Personhood and Corporate Rights}

In the United States, the legal capacity of corporations appears to have been limited up to the nineteenth century. ${ }^{35}$ The case Trustees of Dartmouth College v. Woodward appears as a pivotal moment - the court recognized the College's corporate charter as a contract between two parties (the College

Disobedience in the Name of Sustainability 11 (PM Press Pamphlet Series, 2015).

30 CELDF at 11

31 One viewpoint holds that the system exists to protect the environment. Others who critique the system believe mere reform would be adequate. A newer position harshly criticizes the regulatory system, but posits a guardianship model for land stewardship (see, generally, Wood, Nature's Trust).

32 Art. I, Sec. 8 cl. 3 of the U.S. Constitution.

33 CELDF at 11-12. Likewise, civil rights laws were enacted pursuant to Congress' commerce powers, arguing that African-Americans traveling between states amounted to articles of interstate commerce, meaning Congress had the authority to legislate their protection. See Katzenbach v. McClung, 379 U.S. 294 (1964); Heart of Atlanta Motel Inc. v. U.S., 379 U.S. 241 (1964).

34 CELDF at 12 [emphasis in original].

35 The Yale Law Journal, Constitutional Rights of the Corporate Person, 91 YALE L.J. 1641, 1641 (1982). As late as 1809, U.S. courts still did not recognize corporate personhood. Bank of the United States v. Deveaux, 9 U.S. 61 (1809), partially overruled by Louisville, Cincinnati, and Charleston Railroad Co. v. Letson, 43 U.S. 497 (1844), later superseded by Hertz Corp. v. Friend, 130 S.Ct. 1181, 559 U.S. 77 (2010). 
and the British Crown prior to the Revolution). ${ }^{36}$ This meant that, as a contract, the College's charter received protection under Article I, Section 10 of the Constitution - the "Contracts Clause" - marking an important moment in limiting government and public intervention with private, corporate charters. ${ }^{37}$

Later, in Santa Clara v. Southern Pacific Railroad Co.,${ }^{38}$ the court's decision implied that Equal Protection laws, stemming from the Fourteenth Amendment, applied to corporations. Notably, the court did not conclusively reach that finding. Nevertheless - when the court reporter prepared the case headnotes, ${ }^{39}$ he included a statement attributed to the Chief Justice, claiming that Fourteenth Amendment Equal Protection does apply to corporations. ${ }^{40}$ This case has been used henceforth as a watershed moment where the courts recognized corporate personhood. ${ }^{41}$

While different theories characterize the Court's approach toward bestowing corporations with rights, ${ }^{42}$ corporations have nevertheless amassed a sub-

36 Trustees of Dartmouth College v. Woodward, 17 U.S. 518 (1819); James G. Wright III, A Step Too Far: Recent Trends in Corporate Personhood and the Overexpansion of Corporate Rights, $49 \mathrm{~J}$. Marshall L. Rev. 889, 893 (2015-2016); Program on Corporations, Law \& Democracy (POCLAD), Defying Corporations, Defining Democracy 89 (Dean Ritz ed., The Apex Press, 2001).

37 Dartmouth, 17 U.S. at 518; Id. at 667-68; Wright, A Step Too Far, at 893; POCLAD at 89.

38 Santa Clara v. Southern Pacific Railroad Co., 6 S.Ct. 1132, 118 U.S. 394 (1886).

39 The court reporter was J.G. Bancroft Davis, who had corporate ties as the former President of the Newburgh and New York Railway Company. Headnotes within U.S. case law are brief summaries of important points of law found within a particular case, prepared for the convenience of the profession, but are not legally binding themselves.

40 Santa Clara v. Southern Pacific Railroad Co., 6 S.Ct. 1132, 118 U.S. 394 (1886); Wright, $A$ Step Too Far at 893; POCLAD at 68. The Fourteenth Amendment, adopted on July 9, 1868, was enacted following the U.S. Civil War, with provisions theoretically designed to protect freed slaves, most notably the "Equal Protection" and "Due Process" clauses. Nevertheless, of the 307 cases brought involving the Fourteenth Amendment before the U.S. Supreme Court between 1890 and 1910, only nineteen dealt with the rights of African-Americans, while 288 dealt with corporations. POCLAD at 47-48, John A. Powell \& Stephen Menendian, Beyond Public/Private: Understanding Corporate Power, 19 Race, Poverty \& the Environment 45, 46 (2012). For context, corporate personhood was established in 1886, thirty-four years prior to the ratification of women's right to vote in 1920 via the Nineteenth Amendment. U.S. Const. amend. XIX.

41 Some commentators see this as the defining moment for corporate personhood and corporate rights. Wright, A Step Too Far, at 893. Others are more reserved, arguing the Court parsed the Fourteenth Amendment's clauses, granting corporations equal protection and due process rights only when necessary to protect shareholder property interests. Naomi Lamoreaux \& William Novak, Getting the History Right, SLATE, March 24, 2014, available at http:// wrevreslate.com/articles/newesand_politics/jurisprudence/2014/03/hobby_lobby_and_corporate_personhood_here_s_the_real_history_of_corporate.html (last accessed August 26, 2017). Regardless of the perspective, Santa Clara marks a point where certain civil rights were understood as applying to corporations (and not just to people).

42 For a discussion of some of these different theories, see The Yale Law Journal, Constitutional Rights of the Corporate Person; Wright, A Step Too Far. 
stantial body of legally recognized rights. These include First Amendment rights to commercial speech, ${ }^{43}$ political speech, and freedom of the press; ${ }^{44}$ Fourth Amendment rights against unreasonable searches and seizures; ${ }^{45}$ Fifth Amendment protection against double jeopardy ${ }^{46}$ and uncompensated takings; ${ }^{47}$ a Fifth Amendment right to due process; ${ }^{48}$ a Sixth Amendment right to trial by jury in criminal cases; ${ }^{49}$ a Seventh Amendment right to a trial by jury in civil cases; ${ }^{50}$ and a Fourteenth Amendment right to equal protection $^{51}$ and due process. ${ }^{52}$ Recently, in Burwell v. Hobby Lobby Stores, Inc., the court recognized a for-profit corporation's claim of religious belief (though the Court argued that it limited its finding to "closely held" corporations). ${ }^{53}$

Corporate personhood and corporate rights are an extension of an economically-driven legal framework and philosophy. Early English charters created the colonies - the vehicles of territorial expansion - which were protected by law. ${ }^{54}$ Today, state-issued charters create corporations, which serve as vehicles for the task of expansion, growth, and arguably conquest, and are protected via corporate personhood and corporate rights. ${ }^{55}$ The current situation is merely an extension of the legal framework that began at the country's inception.

That is not to say this system has gone unchecked. To the contrary, people have used creative tactics to oppose corporate power. ${ }^{56}$ Still, the current situ-

43 Virginia State Pharmacy Board v. Virginia Citizens Consumer Council, 425 U.S. 748 (1976).

44 First Nat'l Bank of Bos. V. Bellotti, 435 U.S. 765, 777 (1978); Grosjean v. Am. Press. Co., 297 U.S. 233, 244, 251 (1936); Citizens United v. Fed. Election Comm'n, 558 U.S. 310 (2010). See also Susanna Kim Ripken, Citizens United, Corporate Personhood, and Corporate Power: The Tension Between Constitutional Law and Corporate Power, 6 U. St. Thomas J.L. \& Pub. Pol'y 285 (2011-2012).

45 Hale v. Henkel, 201 U.S. 43, 76 (1906). See also Ripken, Citizens United.

46 U.S. v. Martin Linen Supply Co., 430 U.S. 564, 569, 572 (1977). See also Ripken, Citizens United.

47 Pennsylvania Coal Co. v. Mahon, 260 U.S. 393 (1922).

48 Noble v. Union River Logging R. Co., 147 U.S. 165 (1893).

49 Armour Packing Co. v. United States, 209 U.S. 56, 76-77 (1908).

50 Ross v. Bernhard, 396 U.S. 531, 542 (1970). See also Ripken, Citizens United.

51 See Santa Clara v. S. Pac. R.R. Co., 118 U.S. 394, 396 (1886); Covington \& Lexington Tpk. Rd. Co. v. Sandford, 164 U.S. 578, 592 (1896); Gulf, Colorado E् Santa Fe Ry. Co. v. Ellis, 165 U.S. 150, 154 (1897); Ripken, Citizens United.

52 Minneapolis E St. Louis R.R. v. Beckwith, 129 U.S. 26 (1889).

53 Burwell v. Hobby Lobby Stores, Inc., 134 S.Ct. 2751 (2014).

54 CELDF at 16-17.

55 CELDF at 16-17.

56 Different methods to control corporations have included: denying the issuance of corporate charters when communities opposed a business project; prohibiting incorporated businesses from taking action that legislators did not specifically allow; limiting corporate charters to a set number of years, and dissolving the charter if legislators did not renew it; providing shareholders the power to remove directors at will; asserting State power to take over ownership and control of corporate properties; establishing a fund from corporate 
ation marks a moment where corporations and their advocates are on the winning side of the equation.

This has concrete implications for communities. Because corporations enjoy equal protection and due process rights, once an agency issues a permit, the community has limited legal recourse to cancel or nullify said permit. If a community prohibits a corporation from advancing with the permitted project, the company may sue the community, alleging the community has violated its constitutional rights. The case study of Grant Township, Pennsylvania - discussed below - demonstrates one community's experience that reflects what is outlined above.

Before advancing to the case study, a brief note regarding the community in question is warranted. The community of Grant Township, Pennsylvania, is composed primarily of inhabitants of European-American descent. The positioning of Native communities within the United States as legal subjects is a different positioning than that of communities constituted under the municipal legal framework in the United States; Native communities interact and engage with the U.S. federal government via a different legal framework, grounded in the sovereignty that is recognized for Native communities on Native lands.

The author is familiar with, but not an expert in, the historic and ongoing legal and political challenges confronted by Native communities defending their lives and homelands in the United States. Given a lack of expertise in that particular field, this article does not attempt to extend into the realm of drawing parallels between the challenges faced by indigenous communities in Mexico with those faced by Native American communities in the United States. Rather, working from the experiences on hand, this article seeks to document the similarities that can be identified between an indigenous Mexican community and a European-American-descendant community, as both seek to protect the land they call home.

\section{Case Study: Grant Township, Pennsylvania}

\section{A. PGE v. Grant Township ${ }^{57}$}

Located in the state of Pennsylvania, Grant Township is a small, rural community of roughly 700 residents, most of whom are of European-American descent. In 2017, Pennsylvania General Energy Company, LLG ("PGE") operated natural gas wells in the Township, including a deep gas well. PGE sought to convert the deep gas well into an injection well to deposit fracking

profits to buy private utilities to make them public; forbidding the existence of private banks; prohibiting banks from engaging in trade; and including revocation clauses in corporate charters. POCLAD at 61-71.

57 PGE v. Grant Township, 1:14-cv-209 (W.D. 2014). 
and other oil and gas waste fluids into the well. ${ }^{58}$ Grant Township residents and local officials opposed fracking waste being injected within their community. They expressed concerns about their water, health, and safety. ${ }^{59}$

Grant Township residents originally appealed the permit issued to PGE by the Environmental Protection Agency ("EPA"). ${ }^{60}$ The Environmental Appeals Board ("EAB") did not allow an appeal to proceed. ${ }^{61}$ Seeking a solution, on June 3, 2014, Grant Township residents passed a local law that they entitled a "Community Bill of Rights" ${ }^{62}$ The law sought to recognize rights at the local level, including the people's rights to clean air, clean water, and local self-government, as well as rights of nature. The local law prohibited activities that the people believed would violate those rights, including depositing oil and gas waste within the Township. ${ }^{63}$

On August 12, 2014, PGE sued Grant Township. ${ }^{64}$ PGE's complaint contained thirteen counts, which fell under three main categories. PGE alleged: (1) the law violated PGE's constitutional rights; (2) the Township lacked the authority to adopt the law; and (3) state laws preempt the local law. ${ }^{65}$ On October 13, 2014, Grant Township filed an Answer and Counterclaim, arguing that PGE's lawsuit violated Grant's right to local self-government. ${ }^{66} \mathrm{On}$ December 15, 2014, both parties filed a Motion for Judgment on the Pleadings. ${ }^{67}$ The Court granted PGE's Motion for Judgment on the Pleadings on eight of nine counts, and denied Grant Township's Motion for Judgment on the Pleadings. 68

58 ECF Doc. 158 at 1, PGE v. Grant Township, 1:14-cv-209 (W.D. 2014).

59 Id. at 2.

60 For PGE to operate its well, it must receive permits both from the federal environmental regulatory agency, the EPA, and the state environmental regulatory agency, the Department of Environmental Protection ("DEP").

61 In re Penn. General Energy Co., LLC, UIC Appeal Nos. 14-63, 14-64, \& 14-65, available at: https://yosemite.epa.gov/oa/EAB_Web_Docket.nsf/Published $\% 20$ and $\% 20$ Unpublished\%20Decisions/3E0F361FG07D687B85257D3B0058F11C/\$File/ Pennsylvania\%20General\%20Vol\%2016.pdf (last accessed Aug. 26, 2017).

62 ECF Doc. 158 at 2, PGE v. Grant Township, 1:14-cv-209 (W.D. 2014).

63 Id. at 2-3.

64 The complete case docket for PGE v. Grant Township may be accessed via Pacer using the docket number 1:14-cv-00209.

65 EGF Doc. 158 at 3, EGF Doc. 5, PGE v. Grant Township, 1:14-cv-209 (W.D. 2014).

66 ECF Doc. 158 at 3, ECF Doc. 10, PGE v. Grant Township, 1:14-cv-209 (W.D. 2014).

67 ECF Doc. 158 at 4, ECF Doc. 50, ECF Doc. 52, PGE v. Grant Township, 1:14-cv-209 (W.D. 2014). A Motion for Judgment on the Pleadings in U.S. federal court is filed after the plaintiff has submitted its complaint and the defendant has submitted its answer. It alleges that the opposing party has failed to state a claim upon which relief can be granted, and so the case should be dismissed.

68 ECF Doc. 158 at 4, ECF Doc. 113, PGE v. Grant Township, 1:14-cv-209 (W.D. 2014). In its order (ECF Doc. 113), the court found that: (i) Grant exceeded its legislative authority by prohibiting corporations and governments from depositing oil and gas waste in the township; 
On November 3, 2015, Grant Township adopted a Home Rule Charter, which repealed the challenged law and transformed Grant from a Second Class Township into a home rule municipality. ${ }^{69}$ The Charter included both a bill of rights recognizing the rights that had been included in the repealed law, and a prohibition on depositing oil and gas waste. ${ }^{70}$

Meanwhile, the underlying case on the repealed Community Bill of Rights proceeded. Both parties filed Motions for Summary Judgment ${ }^{71}$ in January 2016. On March 31, 2017, the court granted in part and denied in part PGE's Motion for Summary Judgment, while denying Grant Township's Motion for Summary Judgment. ${ }^{72}$

In 2017 the court attempted to negotiate a settlement between the parties. The parties were unable to reach a settlement, and the case moved forward. ${ }^{73}$

(ii) Grant's prohibition on injecting and storing oil and gas waste improperly excluded legally permitted activities within the Township; (iii) Grant exceeded its authority by prohibiting regulatory agencies from issuing permits to PGE; (iv) Grant exceeded its authority when it created a cause of action for residents to enforce the law; and (v) Grant could not divest PGE of its status as a corporate person.

69 Pennsylvania state law includes the "Home Rule Charter and Optional Plans Law." 53 Pa.C.S.A. § 2901, et seq. This statute allows Pennsylvania municipalities to adopt a "home rule charter", which serves as the municipality's organic governing document, akin to a local municipal constitution. The concept of home rule gained traction in the United States during the 1970s. Progressive reforms were advocated throughout the country, and efforts to establish greater local autonomy lead to a push for home rule in many states. In Pennsylvania, if a municipality is "home rule," it has greater control over its local affairs than non-home rule municipalities.

70 Home Rule Charter of the Township of Grant, Indiana County, Pennsylvania (Aug. 25, 2015).

71 In U.S. federal court, a motion for summary judgment occurs after the litigation stream has begun, but before the case has reached trial. Summary judgment theoretically allows the case to be resolved without trial. To win a summary judgment motion, the moving party must show there is no genuine dispute of material fact, and that the moving party is entitled to judgment as a matter of later. ECF Docs. 154-156, 157-159, PGE v. Grant Torenship, 1:14-cv209 (W.D. 2014).

72 ECF Docs. 241-243, PGE v. Grant Township, 1:14-cv-209 (W.D. 2014). The court found PGE already achieved some of the relief it sought via its Motion for Judgment on the Pleadings, but that its constitutional claims remained viable. The Court dismissed PGE's Supremacy Clause claim, Procedural Due Process claim, and Contracts Clause claim. However, the Court granted PGE's Equal Protection claim, finding the law discriminated against corporations because it applied only to corporations and governments, and not to individuals. The Court granted PGE's First Amendment claim. Because the law prohibited PGE from being recognized as a person or enjoying corporate rights, the Court found the law encroached on PGE's right under the Petition Clause of the First Amendment to make a complaint to, or seek the assistance of, the government for the redress of grievances. The Court granted PGE's Due Process claim, finding the law encroached upon corporate constitutional protections. ECF Doc. 241, PGE v. Grant Township, 1:14-cv-209 (W.D. 2014).

73 ECF Doc. 254, PGE v. Grant Township, 1:14-cv-209 (W.D. 2014). 


\section{B. Intervenors in PGE v. Grant Township}

Though PGE sued Grant Township, other actors also sought to participate in the case. On October 23, 2014, the Pennsylvania Independent Oil \& Gas Association ("PIOGA") sought to intervene in the case. PIOGA is "a Pennsylvania nonprofit trade association that represents individuals and corporations with interests in Pennsylvania's oil and natural gas industry. PIOGA's members include oil and natural gas producers, drilling contractors, service companies, manufacturers, distributors, professional firms, and consultants."74

On November 18, 2014, the East Run Hellbenders Society, Inc. ("Hellbenders") and the Little Mahoning Watershed ("Watershed") moved to intervene. ${ }^{75}$ The Hellbenders is a civil society group, composed of concerned citizens living in Grant Township. The Little Mahoning Watershed encompasses the Little Mahoning Creek and the regional natural communities and ecosystems; Grant Township falls within the Watershed's borders. ${ }^{76}$

On October 14, 2015, the court granted PIOGA's intervention in the case. ${ }^{77}$ On the same day, the court denied intervention for both the Hellbenders and the Watershed. ${ }^{78}$

On November 20, 2015, both the Hellbenders and the Watershed appealed the denial of intervention to the Third Circuit. ${ }^{79}$ On July 27, 2016, the Third Circuit issued its non-precedential opinion, denying intervention and affirming the district court. ${ }^{80}$

74 EGF Doc. 16 at 1, PGE v. Grant Township, 1:14-cv-209 (W.D. 2014). PIOGA sought to intervene arguing that because a number of oil and gas well operators within Grant Township are PIOGA members, the law would "divest its members who operate in Grant Township of their fundamental rights, including, among others, their rights under the First and Fourteenth Amendment and the Supremacy Clause of the United States Constitution." ECF Doc. 16 at 1-2, PGE v. Grant Township, 1:14-cv-209 (W.D. 2014).

75 EGF Doc. 37-38, PGE v. Grant Township, 1:14-cv-209 (W.D. 2014). The Hellbenders argued that as residents of Grant Township, they directly benefitted from the recognition of civil rights in the ordinance that was enacted in the Township and should be allowed to defend the local law. The Watershed argued that as the ecosystem whose rights are recognized in the ordinance, it benefitted from and should be allowed to defend the ordinance and corresponding rights.

76 Brief of Petitioner-Appellant at 11, PGE v. Grant Township, No. 15-3770 (3d Cir. Jan. 11, 2016).

77 ECF Doc. 116, PGE v. Grant Township, 1:14-cv-209 (W.D. 2014).

78 Id. at 115. The court deemed representation by the Board of Supervisors to be sufficient to vindicate the rights and interests of the Hellbenders and Watershed, notwithstanding arguments to the effect that, as an elected body, the Board of Supervisors might change personnel and adopt a different posture toward defending the law.

79 Little Mahoning Watershed and East Run Hellbenders Society, Inc.'s Joint Notice of Appeal, PGE v. Grant Township, No. 15-3770 (3d Cir. Nov. 20, 2015).

80 Judgment, PGE v. Grant Township, No. 15-3770 (3d Cir. July 27, 2016). The Third Circuit found that the proposed intervenors' interest in the case was nearly identical to that 
Esta revista forma parte del acervo de la Biblioteca Jurídica Virtual del Instituto de Investigaciones Jurídicas de la UNAM

\section{Pushback to Community Opposition}

In addition to being sued by PGE, Grant Township's opposition to the injection well received other forms of pushback.

On October 31, 2014, PGE issued multiple notices of deposition, seeking to depose Grant Township's elected officials. ${ }^{81}$ PGE also subpoenaed Grant's legal counsel, seeking access to privileged attorney-client communications. ${ }^{82}$ After Grant Township filed a Motion for a Protective Order, PGE withdrew its notices of deposition and subpoena on December 15, 2014. ${ }^{83}$

When PIOGA was granted intervention on October 14, 2015, it filed an ethics complaint with the state Office of Disciplinary Counsel against Grant's attorney. ${ }^{84}$ The Office investigated and dismissed the complaint on November $24,2015 .^{85}$

On January 15, 2016, PGE filed a Motion for Sanctions, arguing that Grant and its counsel were pursuing frivolous legal claims and defenses, and that allowing Grant to proceed would abuse the litigation system and court resources. ${ }^{86}$ On September 30, 2016, the court dismissed the Motion for Sanctions. ${ }^{87}$

On June 2, 2017, PGE filed a second Motion for Sanctions. ${ }^{88}$ PGE sought sanctions against Grant Township, its counsel, and against counsel for the Hellbenders and Watershed. ${ }^{89}$

On August 4, 2017, PIOGA indicated its intent to file for sanctions against Grant Township and its counsel. ${ }^{90}$ PIOGA also indicated a desire to see criminal charges brought against Grant Township local elected officials."91

of the Township Board of Supervisors, and that the Supervisors adequately represented the proposed intervenors' interests, and therefore denied intervention.

81 ECF Doc. 21 at 5-6, PGE v. Grant Torenship, 1:14-cv-209 (W.D. 2014).

82 Id.

83 Case Management Order of Dec. 15, 2014, PGE v. Grant Township, 1:14-cv-209 (W.D. 2014).

84 ECF Doc. 166-2, PGE v. Grant Township, 1:14-cv-209 (W.D. 2014).

85 Id.

86 ECF Doc. 161, PGE v. Grant Township, 1:14-cv-209 (W.D. 2014).

87 ECF Doc. 224, PGE v. Grant Township, 1:14-cv-209 (W.D. 2014).

88 ECF Doc. 249-250, PGE v. Grant Township, 1:14-cv-209 (W.D. 2014).

89 ECF Doc. 249-250, PGE v. Grant Township, 1:14-cv-209 (W.D. 2014).

90 ECF Doc. 266-1, PGE v. Grant Township, 1:14-cv-209 (W.D. 2014).

91 Anya Litvak, Oil and gas industry group ponders criminal prosecution of local officials, Pittsburgh Post-Gazette, Oct. 4, 2016, available at: http://powersource.post-gazette.com/powersource/policypowersource/2016/10/04/Oil-and-gas-industry-group-ponders-criminal-prosecution-of-local-officials/ stories/201610040004 (last accessed Aug. 26, 2017). 
Esta revista forma parte del acervo de la Biblioteca Jurídica Virtual del Instituto de Investigaciones Jurídicas de la UNAM

D. DEP ข. Grant

While the above-mentioned case was in process, on March 30, 2015, PGE applied to the state environmental regulatory agency, the Department of Environmental Protection ("DEP"), for the requisite state permit.

On August 12, 2015, the DEP suspended its review of PGE's permit application pending a court decision on the above case. ${ }^{92}$

On November 3, 2015, Grant Township citizens adopted the Home Rule Charter. The Charter prohibited and criminalized the issuance of a government permit that would allow a corporation to deposit oil and gas waste in the community. ${ }^{93}$

On March 27, 2017, the DEP issued a permit to PGE, and sued Grant Township and its elected officials, arguing that: (1) Grant did not have the authority to prohibit the DEP from issuing the permit; (2) state law preempts local law; and (3) Grant could not impose a fine or criminalize state government action. ${ }^{94}$ DEP also argued that Grant Township should have appealed the permit, rather than prohibit its issuance. ${ }^{95}$ Litigation in this case is ongoing.

\section{E. Additional Actions}

Grant Township additionally enacted a local law stating that if a court failed to uphold the Charter's limitations on corporate power, the local residents could enforce the Charter themselves. That ordinance stated that neither criminal charges, nor civil or criminal actions, could be brought against direct action participants. ${ }^{96}$

On April 25, 2017, the Hellbenders filed an appeal of the DEP's well permit to PGE with the state Environmental Hearing Board, which can be accessed via Docket No. 2017-031-R.

\section{F. Conclusions}

Given the historical and theoretical background, combined with the experience of Grant Township, several key questions and issues arise.

92 PGE v. Grant Township, 1:14-cv-209 (W.D. 2014).

93 Home Rule Charter of the Township of Grant, Indiana County, Pennsylvania, §§ 301, 303 (Aug. 25, 2015).

94 Petition for Review in the Nature of Complaint Seeking Declaratory and Injunctive Relief, DEP v. Grant Township, 126 MD 2017 (Commw. Ct. 2017), filed (March 27, 2017).

95 Id.

96 Grant Township Ordinance, Establishing a Right to Be Free from Prosecution for Direct Action Carried Out to Enforce the Grant Township Home Rule Charter's Rights and Prohibitions; Legalizing Direct Action Enforcement of the Grant Township Home Rule Charter's Rights and Prohibitions, § 2 (May 3, 2016). 
First, a community opposing the issuance of a permit for a corporate project appears to be in a difficult situation. The procedure for appealing a permit may not yield the results that a community seeks; if that occurs, there do not appear to be other effective legal avenues for the community to take. The unanswered question then becomes - what does a community do in such a situation? Can the legal system respond in a way to address a concern that, at its heart, involves questions surrounding democratic governance? If the answer to the latter question is "No," is that acceptable for a democratic system?

Second, corporate rights are a powerful legal tool that can be used to block community opposition to corporate projects, as seen by the Court's affirmation of PGE's corporate rights, and the Court's subsequent decisions supporting PGE's rights over the relief sought by the community.

There is an open question, then, as to whether the current legal framework is one that adequately protects communities and human rights, or if it is instead structurally skewed to favor corporate interests. If the latter is the case, then the urgent question to be addressed involves seeking a way to transform the existing framework into a form that places greater importance on human rights than corporate rights.

\section{Final Reflections}

\section{On the Legal Frameworks}

In addition to having had two Constitutions prior to the current one, Mexico has experienced over 600 constitutional reforms by 2015. The most recent Mexican Constitution enshrined protections for land and communities.

The United States was first governed under the Articles of Confederation, but has had only one Constitution, which has undergone relatively few amendments. Protections for land and the environment were developed in the 1970s with the advent of environmental law and the environmental regulatory system.

Despite the protective frameworks that exist both in Mexico and the United States, changes have occurred to whittle away at those frameworks, favoring corporate interests that seek access to land and resources.

In Mexico, a de facto change in the Constitution, without the hassle of a constitutional convention, transpired with the privatization of the country's energy matrix and the neoliberal counter-reforms that have allowed private capital access to previously protected communal lands. In the United States, case law has evolved to bestow rights upon corporations that serve as a bulwark against community opposition to corporate projects. Both shifts in the underlying legal frameworks provide concerning scenarios for the ability to engage in democratic governance within both countries. 


\section{On Human Rights}

Mexico possesses a body of human rights law that is considerable in size and closely tied to the international human rights legal system.

Despite being a proponent of the Universal Declaration of Human Rights of 1948 and home of the headquarters of the United Nations, the United States has limited its participation in international human rights legal instruments.

Yet both countries, regardless of their public posture on human rights before the international community, demonstrate current structural features that appear to privilege corporate interests over human rights.

\section{On Historical Processes}

In Mexico, national liberation was not accompanied by the liberation of all sectors of society. Economic class and racial hierarchies remained a governing reality, with a newly installed economy closely tied to an increasingly vigorous world economy.

In the United States, the Revolution achieved national liberation, but did not extend to fulfilling the democratic hopes of all peoples, particularly women, indigenous communities, or slaves and people of African descent.

\section{On Consultations and Public Hearings}

Mexican law provides for the legal right to consultation on all environmental matters, which is regularly ignored or unfulfilled. And, in the United States, the corresponding government environmental agency must hold public hearings before issuing any permits. However, the hearings are not required to be dialogues, and community input is non-binding. In both scenarios, an underlying question regarding the ability for citizens and residents to actually participate in the decision-making for their community is raised.

\section{On the Privileged Status of Corporations}

In Mexico, the step-by-step deregulation of the Mexican State has transformed it into a corporate State, as opposed to a social welfare state. Due to neoliberal reforms that have opened up access for capital to the country's energy matrix, corporations have been able to safeguard their investments.

In the United States, corporations enjoy corporate rights that help elevate their status in the eyes of the law. While corporations do not enjoy all of the rights recognized for human beings, they have obtained a sufficient number 
Esta revista forma parte del acervo de la Biblioteca Jurídica Virtual del Instituto de Investigaciones Jurídicas de la UNAM

to allow them to control the fate of lands, properties, and individuals, especially when it comes to the interests of industrial projects.

\section{On Democratic Governance}

In Mexico, the underlying framework of governance established through the process of the Mexican Revolution has undergone counter-reforms that have reduced or eliminated democratic protections, permitting corporate interests to gain access to land and resources.

In the United States, structural concerns found within the environmental regulatory system and the legal doctrine of corporate rights present challenges to actual democratic praxis on the part of communities.

For both countries, the corresponding populations are faced with the serious task of determining which aspects of the current legal framework preclude, rather than enhance, democratic governance. From there, they must find a path forward that counteracts those forces and places the law squarely in the hands of the people most affected by governing decisions that are taken regarding the lands upon which they live. 